\title{
Stratigraphy, sedimentology and bulk organic geochemistry of black shales from the Proterozoic Vindhyan Supergroup (central India)
}

\author{
S BANERJEE ${ }^{1, *}, \mathrm{~S}_{\text {Dutta }}^{2}, \mathrm{~S} \mathrm{PAIKARAY}^{1}$ and U MAnN ${ }^{2}$ \\ ${ }^{1}$ Department of Earth Sciences, Indian Institute of Technology Bombay, Powai, Mumbai 400 076, India. \\ ${ }^{2}$ Forschungszentrum Jülich, Institut für Chemie und Dynamik der Geosphäre, Sedimentäre Systeme, \\ D-52425 Jülich, Germany. \\ *e-mail: santanu@iitb.ac.in
}

Four organic-rich shale units of the Proterozoic Vindhyan sedimentary succession have been scanned to reveal their origin and hydrocarbon potential. The wavy-crinkly nature of the carbonaceous laminae is suggestive of a microbial mat origin of the shales. These shales are thus different from Phanerozoic black shales which typically exhibit planar laminae. The hydrocarbon potential of the black shale units has been evaluated by Rock-Eval pyrolysis. Total organic carbon content of many of the shales exceeds $1 \%$. The mean $T_{\max }$ for the black shales translate to a vitrinite reflectance range of $2.05-2.40 \% \mathrm{Rm}$ based on standard conversion techniques. These shales have reached the catagenetic stage near the beginning of anthracite formation.

\section{Introduction}

Proterozoic shales are generally organic-poor and are considered insignificant hydrocarbon source rocks (Hunt 1995). However, organic-rich shales are reported from many Proterozoic basins (Condie et al 2001 and references therein) and some of them probably sourced ancient petroleum accumulations. At places these organic-rich shales are considered as possible hydrocarbon source rocks, viz., in the Rice Formation (Newell et al 1993) and Nonesuch Formation, U.S.A (Imbus et al 1988). Organic-rich (TOC up to 7\%), mature kerogens of the Mesoproterozoic Velkerri Formation and Barney Creek Formation of Australia are comparable to potential Phanerozoic hydrocarbon source rocks and have been targeted for oil exploration (Crick 1992; Warren et al 1998). A low degree of thermal alteration characterizes both these shales. Organic-rich shales of Neoproterozoic have sourced a number of oil and gas fields in the Sichuan basin of China (Korsch et al 1991). Biomarker analysis of these organic-rich shales provides insights into the early evolution of microbial life (Buick et al 1998; Dutkiewicz et al 2002; Greenwood et al 2004 and references therein). The $\mathrm{C}-\mathrm{S}-\mathrm{Fe}$ relationship of such shales highlights the sedimentary processes (Jackson and Raiswell 1991; Hieshima and Pratt 1991). Study of such shales may also provide valuable clues related to the burial history of Proterozoic sedimentary basins (Korsch et al 1991; Crick 1992; Newell et al 1993) and estimates for paleogeothermal gradient (Price et al 1996).

Organic richness is indicated for the Proterozoic Vindhyan shales but its source rock potential is yet to be evaluated (Shukla and Chakraborty 1994). Petrographic and geochemical investigations of the black shales are in the nascent stage (Sur et al 2002, 2003, 2004; Banerjee and Schieber 2003). Quality and maturation of organic matter of these black shales are yet to be estimated. Maturation data are essential in order to reveal the hydrocarbon generating potential of the shales and thermal history of the Vindhyan basin.

Keywords. Proterozoic; black shales; microbial mat; kerogen; maturation; catagenesis.

J. Earth Syst. Sci. 115, No. 1, February 2006, pp. 37-47

(C) Printed in India. 


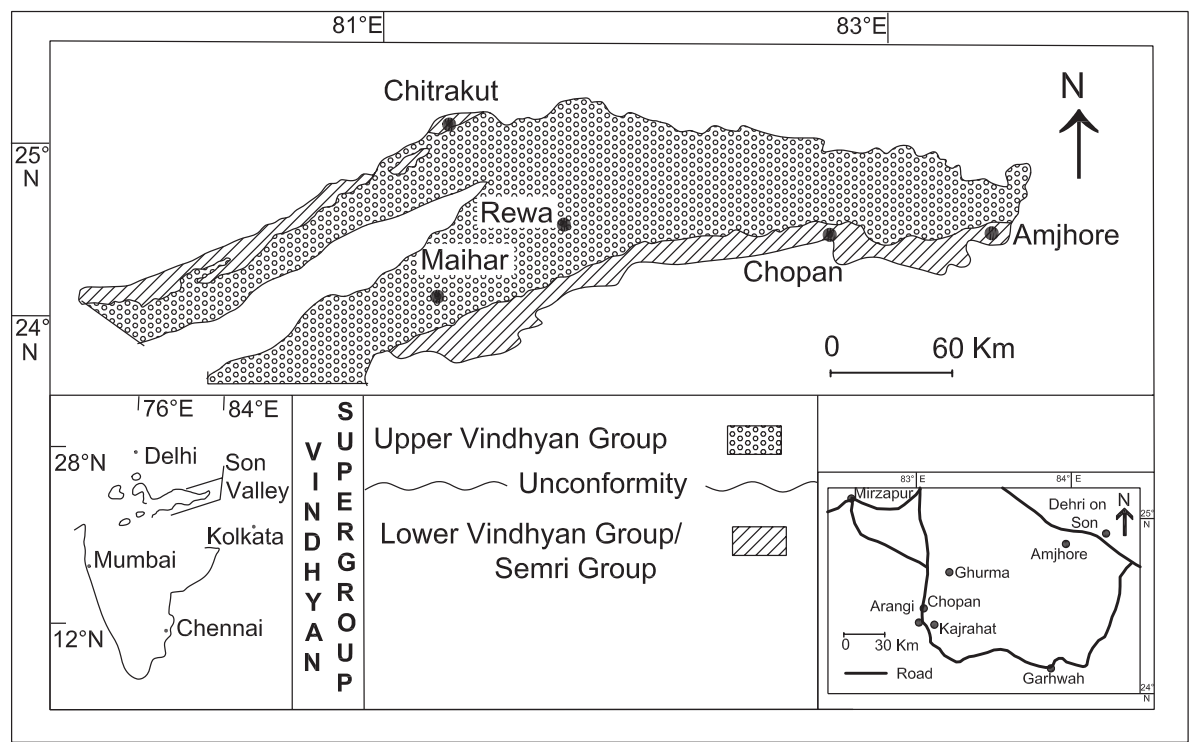

Figure 1. Geological map showing outcrop distribution of the Vindhyan basin in the Son valley area (modified after Auden 1933). Map of India within inset (left bottom) and location map of the study areas (right bottom).

This paper presents some new results and a brief discussion on the stratigraphy and sedimentology of the black shales of the Proterozoic Vindhyan basin in the Son valley area, and provides bulk characteristics of their organic matter content. Quantity, quality and maturation of organic matter of individual black shale formations are estimated and assessed separately. Specific attention is given to the temperature of the maximum pyrolitic degradation of organic matter in order to estimate its catagenetic stage.

\section{Geological setting}

Outcrops of the Vindhyan Supergroup cover vast areas in the Son valley area, central India (figure 1). The Vindhyan sedimentary succession is two-tiered; an unconformity and its correlative conformity surfaces divide the Vindhyan Supergroup into Lower Vindhyan Group (also known as Semri Group) and Upper Vindhyan Group (Bose et al 2001) (figure 1). The Semri Group consists of carbonates, siliciclastics and volcaniclastics, whereas, the Upper Vindhyan Group is dominated by siliciclastics with minor carbonates (figure 2). The Vindhyan sedimentary rocks are mostly marine, possibly deposited in an E-W elongated epeiric sea opening westward (Chanda and Bhattacharyya 1982; Bose et al 2001). Available age dating suggests that the Vindhyan sediments bracket an age range between $1.7 \mathrm{Ga}$ and $0.6 \mathrm{Ga}$ (Rasmussen et al 2002; Ray et al 2002, 2003; Sarangi et al 2004; figure 2). Despite its very old age and huge thickness of sediments (up to $4500 \mathrm{~m}$, Ahmad 1958) the
Vindhyan sediments are mildly deformed and a little metamorphosed.

Vindhyan shales are mostly grey-to-green in colour and poor in organic content (Paikaray et al 2003). Nevertheless four black shale units are identified in the following formations:

- Deoland Formation,

- Kajrahat Formation,

- Rohtas Formation and

- Kaimur Formation (figure 2).

Black shale units in the last two formations are thicker, laterally persistent and have formal stratigraphic names, e.g., Rampur Shale and Bijaigarh Shale. A 1.7 to $1.6 \mathrm{Ga}$ age is ascribed for the three black shale units of the Semri Group (figure 2). The age of the black shale unit in Upper Vindhyan Group (Bijaigarh Shale) is uncertain because of the inconsistency in radiometric dates, but on the basis of available data a Mesoproterozoic age is inferred (Venkatachala et al 1996).

\section{Samples and methods}

The present work has two components, e.g., sedimentological studies involving field and petrographic observations of black shales, and laboratory studies in organic geochemistry.

\subsection{Sampling}

Three of the black shale units belonging to the Semri Group were studied and sampled in a N-S 


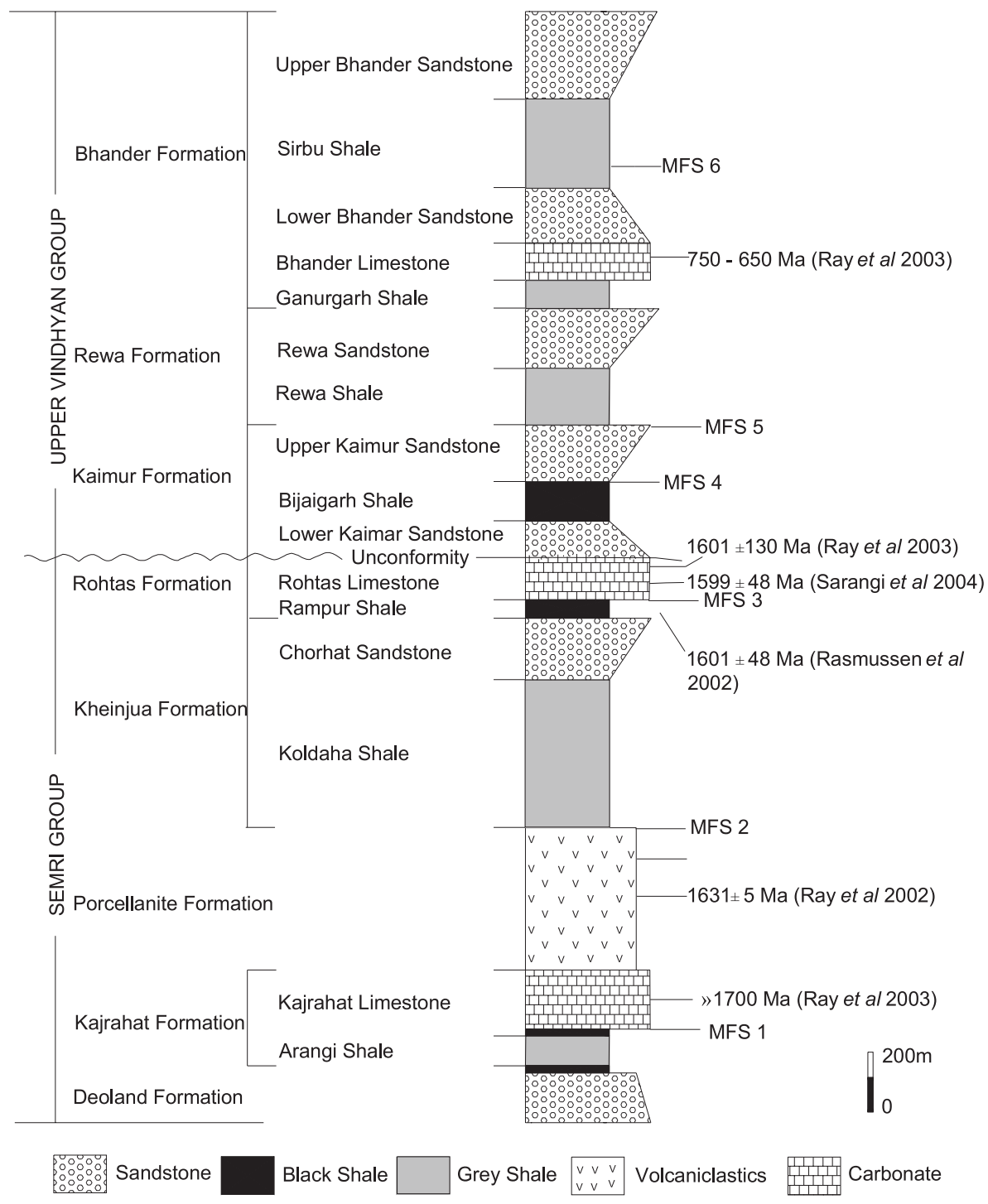

Figure 2. Vertical section showing occurrences of black shales and depositional trends within the Vindhyan sedimentary succession. Detailed stratigraphy of the Vindhyan Supergroup up to member level is presented in the left column and recent age dating is provided to the right of the vertical section. Maximum flooding surfaces in the Vindhyan megasequence are indicated by $\mathrm{mfs} 1$ to $\mathrm{mfs} 6$ on the right. The trends of stratigraphic units and positions of maximum flooding surfaces are from Banerjee (1997) and Bose et al (2001). Note stratigraphic positions of the four black shale units of the Vindhyan Supergroup. Two thin black shale units are exaggerated in the section.

traverse through Chopan (figure 1). The black shale unit of the Upper Vindhyan Group (Bijaigarh Shale) was documented and sampled near Amjhore Pyrite Mines (figure 1). All the samples were collected from outcrops in the exposed sections. Organic geochemical analyses were conducted on thirteen fresh samples. For the Deoland Formation only one sample was analysed and from each of the remaining three black shale units four samples were analysed.

\subsection{Sedimentological studies}

Black shales were documented by erecting logs from the measurement of spot thicknesses of shales and associated lithologies in cliff sections and small quarries. Sedimentary structures within the black shale and associated lithologies were recorded in the field. Fresh samples were collected taking into account their exact stratigraphic positions. Thin sections of shales were prepared from the samples with dimensions approximately $2 \mathrm{~cm} \times 3 \mathrm{~cm} \times 1 \mathrm{~cm}$. Samples were then coated with epoxy solutions A and B (prepared by Hillquist, U.S.A.). Immediately after the coating, samples were kept in a vacuum chamber for an hour so that the epoxy solution can enter through the fractures and pore spaces of the shale samples and make it very hard. The hardened samples were taken for further cutting and polishing. On an average five sections from 
Table 1. Individual results of elemental analyses for total carbon (TC), total organic carbon (TOC), total sulphur (TS), volatilized hydrocarbons present in the rock (S1), volatilized hydrocarbons and related compounds generated by pyrolysis of insoluble kerogen (S2), calculated hydrogen index (HI), and $T_{\max }$ representing the temperature of maximum pyrolytic degradation of kerogen.

\begin{tabular}{|c|c|c|c|c|c|c|c|c|}
\hline $\begin{array}{l}\text { Sample ID } \\
\text { (field) }\end{array}$ & Stratigraphy & $\begin{array}{l}\mathrm{TC} \\
(\%)\end{array}$ & $\begin{array}{c}\text { TOC } \\
(\%)\end{array}$ & $\begin{array}{l}\mathrm{TS} \\
(\%)\end{array}$ & $\begin{array}{c}\mathrm{S} 1 \\
(\mathrm{mg} \mathrm{HC} / \mathrm{g} \\
\text { sample) }\end{array}$ & $\begin{array}{c}\mathrm{S} 2 \\
\text { (mg HC/g } \\
\text { sample) }\end{array}$ & $\begin{array}{c}\mathrm{HI} \\
\underset{\mathrm{TOC}}{\mathrm{mg} \mathrm{HC}} / \mathrm{g}\end{array}$ & $\begin{array}{l}T_{\max } \\
\left({ }^{\circ} \mathrm{C}\right)\end{array}$ \\
\hline B4 & Bijaigarh Shale (top shale) & 3.88 & 3.83 & 16.50 & 0.01 & 0.14 & 4 & 551 \\
\hline B6 & Bijaigarh Shale (top shale) & 4.15 & 4.15 & 13.75 & 0.01 & 0.12 & 3 & 548 \\
\hline B9 & Bijaigarh Shale (bottom shale) & 1.91 & 1.89 & 0.02 & 0.01 & 0.02 & 1 & 536 \\
\hline B11 & Bijaigarh Shale (bottom shale) & 1.54 & 1.53 & 0.02 & 0.01 & 0.03 & 2 & 533 \\
\hline Rh-1 & Rampur Shale & 5.72 & 0.94 & 0.20 & 0.01 & 0.04 & 4 & 537 \\
\hline Rh-2 & Rampur Shale & 3.60 & 1.27 & 0.50 & 0.01 & 0.05 & 4 & 538 \\
\hline Rh-5 & Rampur Shale & 5.16 & 1.08 & 0.45 & 0.01 & 0.05 & 5 & 537 \\
\hline RH-9 & Rampur Shale & 3.96 & 0.79 & 0.38 & 0.01 & 0.05 & 6 & 538 \\
\hline Kaj-1 & Kajrahat Formation & 2.91 & 2.74 & 0.05 & 0.00 & 0.02 & 1 & 537 \\
\hline Kaj-3 & Kajrahat Formation & 2.81 & 2.64 & 0.25 & 0.00 & 0.02 & 1 & 539 \\
\hline Kaj-5 & Kajrahat Formation & 3.34 & 2.63 & 0.18 & 0.01 & 0.03 & 1 & 541 \\
\hline $\mathrm{Kaj}-7$ & Kajrahat Formation & 3.63 & 3.14 & 0.31 & 0.01 & 0.03 & 1 & 539 \\
\hline DL-1 & Deoland Formation & 6.44 & 6.44 & 0.24 & 0.01 & 0.02 & 2 & 542 \\
\hline
\end{tabular}

each of the four black shale units were examined. Photomicrographs of shales were taken with the help of a Nikon Eclipse E 600 Pol microscope with the attached Nikon coolpix 8700 digital camera. A few of the thin sections were stained (Dickson 1966).

\subsection{Organic geochemistry}

Thirteen selected samples from the four different black shale units were chosen for analysis of the amount, quality and maturity of organic matter (table 1).

Total carbon (TC) and sulphur content (TS) of the samples were measured by combustion of the homogenized rock powders at a temperature of $2000^{\circ} \mathrm{C}$ in an oxygen-rich environment ( $L E C O$ CS-225 Analyzer) in the Institute for Chemistry and Dynamics of the Geosphere (ICG V), Jüelich. The resulting $\mathrm{CO}_{2}$ and $\mathrm{SO}_{2}$-gas phases were determined simultaneously by an infrared detection system. Total organic carbon (TOC) contents were measured in the same way after removal of the inorganic carbon with $24 \%$ hydrochloric acid.

Characterization of the finely disseminated organic material was performed using a Rock-Eval Delsi II pyrolyzer (Espitalie et al 1977). Small amounts $(\sim 100 \mathrm{mg})$ of the powdered rock samples were pyrolysed under an inert He-atmosphere according to a specific time/temperature program (figure 3 ). The following temperature and

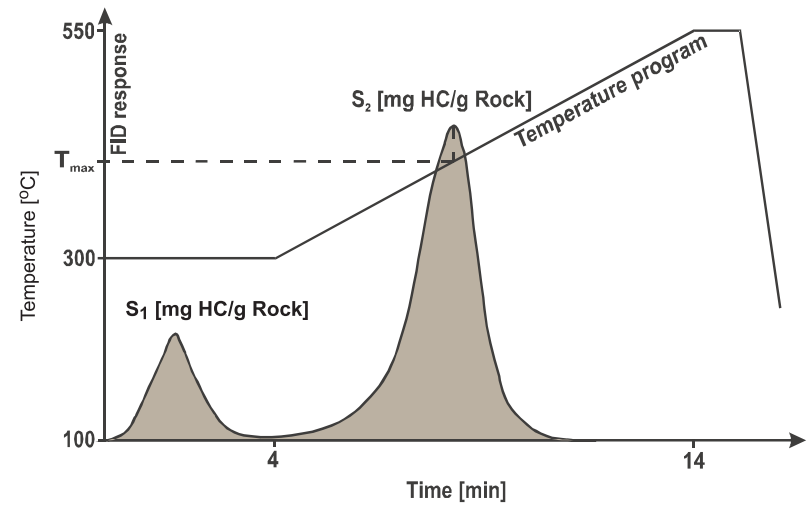

Figure 3. Schematic Rock-Eval pyrogram displaying time-temperature relationships and the amount of volatilized hydrocarbons present in the rock (area of the $\mathrm{S}_{1}$ peak), and the amount of volatilized hydrocarbons and related compounds generated by pyrolysis of insoluble kerogen (area of the $\mathrm{S}_{2}$ peak). $T_{\max }$ represents the temperature at which the maximum pyrolytic degradation of kerogen occurs and accordingly the highest amount of hydrocarbons are released.

time intervals correspond to the flame ionizationdetected hydrocarbon amounts, expressed as $\mathrm{S}_{1}$ and $S_{2}$ peaks, respectively:

$\mathrm{S}_{1}$ - isothermal $300^{\circ} \mathrm{C}$ during $3 \mathrm{~min}$ : volatilisation of soluble organic matter (liquid and/or adsorbed hydrocarbons).

$\mathrm{S}_{2}$ - constant heating rate of $25^{\circ} \mathrm{C} / \mathrm{min}$ from $300^{\circ} \mathrm{C}$ up to $550^{\circ} \mathrm{C}$ : hydrocarbons derived solely from the cracking of the residual organic matter (kerogen). 
In this study the $\mathrm{CO}_{2}$ content coming from the cracking of kerogen $\left(\mathrm{S}_{3}\right.$-peak) is not taken into consideration because of the early decomposition of carbonate minerals below the $\mathrm{CO}_{2}$ trapping temperature of $390^{\circ} \mathrm{C}$ due to mineral matrix effects. This produces additional $\mathrm{CO}_{2}$, which leads to elevated oxygen indices (Katz 1983). All values are means of double determinations calibrated on an international standard distributed by the Institute Francaise du Pétrole, France (IFP 55000).

\section{Results and discussion}

\subsection{Re-evaluation of the sequence stratigraphic frame of the black shale units}

Sequence stratigraphic context of the black shale units is presented here taking into account the detailed depositional facies successions discussed elsewhere (Banerjee 1997; Bose et al 2001). Vindhyan Supergroup represents a megasequence; an unconformity and its correlative conformity surfaces divide the Vindhyan Supergroup into two sequences. Each of these sequences contains three maximum flooding surfaces (MFS, figure 2). The oldest black shale unit occurs at the top of the Deoland Formation which is conglomeratic in the basal part and fines upward into sandstones. Together with the overlying Arangi Shale it forms a transgressive systems tract (TST) (Van Wagoner et al 1990). The black shale unit thus occurs towards the top part of the transgressive systems tract. The next black shale unit occurs above this TST (figure 2). The overlying Kajrahat Limestone is overall shallowing upward in nature and considered as a high stand systems tract (HST) (Sarg 1988). The black shale unit, thus transitional between a transgressive systems tract and a highstand systems tract, represents condensed zone deposits in an outer shelf setting. The maximum flooding surface (MFS, Galloway 1990) should occur at the base of the Kajrahat Limestone (figure 2). The next black shale unit is Rampur Shale which overlies the Chorhat Sandstone. Rampur Shale gradationally passes over to the Rohtas Limestone which is mostly inner shelf in origin, overall prograding and considered as a high stand systems tract. The Rampur Shale thus represents possible condensed zone deposits with the maximum flooding surface occurring at the base of the Rohtas Limestone (figure 2). The only black shale unit of the Upper Vindhyan Group is the Bijaigarh Shale which gradationally overlies Lower Kaimur Sandstone. The Bijaigarh Shale is overall upward fining and together with the underlying Lower Kaimur Sandstone forms a transgressive systems tract (TST). Pyritiferous, dark-coloured shales of the Bijaigarh Shale possibly represent condensed zone deposits.

Thus, except for the black shale unit of the Deoland Formation, the black shale units are associated with condensed zones and incorporate maximum flooding surfaces. The remaining three maximum flooding surfaces ( $\mathrm{mfs} 2, \mathrm{mfs} 5$ and $\mathrm{mfs} 6$ ) are not associated with black shales, although organic content may reach $0.5 \%$ in the shales (Paikaray et al 2003).

\subsection{Black shales of the Vindhyan basin}

A brief description of each black shale unit and its paleogeographic interpretation is provided below. Detailed facies analysis of the shale units is beyond the scope of this paper. Paleogeography of the black shale units is interpreted taking into consideration the depositional facies succession of the Vindhyan Supergroup described in detail by Banerjee (1997) and Bose et al (2001).

\subsubsection{Black shales in Deoland Formation}

The oldest of the black shale unit of the Vindhyan basin occurs in an isolated exposure near the top part of the Deoland Formation in Arangi village (figure 1). The Deoland Formation is overall upward fining. Its lower part is dominantly sandy and the upper part consists of alternations between shales and siltstones/fine sandstones; it gradationally passes into Arangi Shale. The black shale unit occurs as a lenticular body within the fine siliciclastics of the Deoland Formation and its maximum thickness is up to $1.5 \mathrm{~m}$ (figure 2). Dark coloured coaly shales alternate with thin siltstones and fine sandstone beds (up to $4 \mathrm{~cm}$ in thickness).

Detailed study of this black shale unit is not possible because of its very local occurrence and poor exposure. Limited petrographic observations reveal wavy and crinkly laminae within the black shales. The black shale unit occurs towards the top of the Deoland Formation and possibly represents deposition in an outer shelf setting. The presence of thicker siltstone bands (up to $4 \mathrm{~cm}$ ) suggests that deposition possibly took place in offshore setting above the storm wave base.

\subsubsection{Black shales in Kajrahat Formation}

The base of the Kajrahat Limestone in the Kajrahat area (figure 1) is characterized by $12.5 \mathrm{~m}$ thick interval of black shale-dolomite alternations. Within this interval black shales alternate with either plane laminated dolomite (av. thickness 
Middle division of Kajrahat Limestone

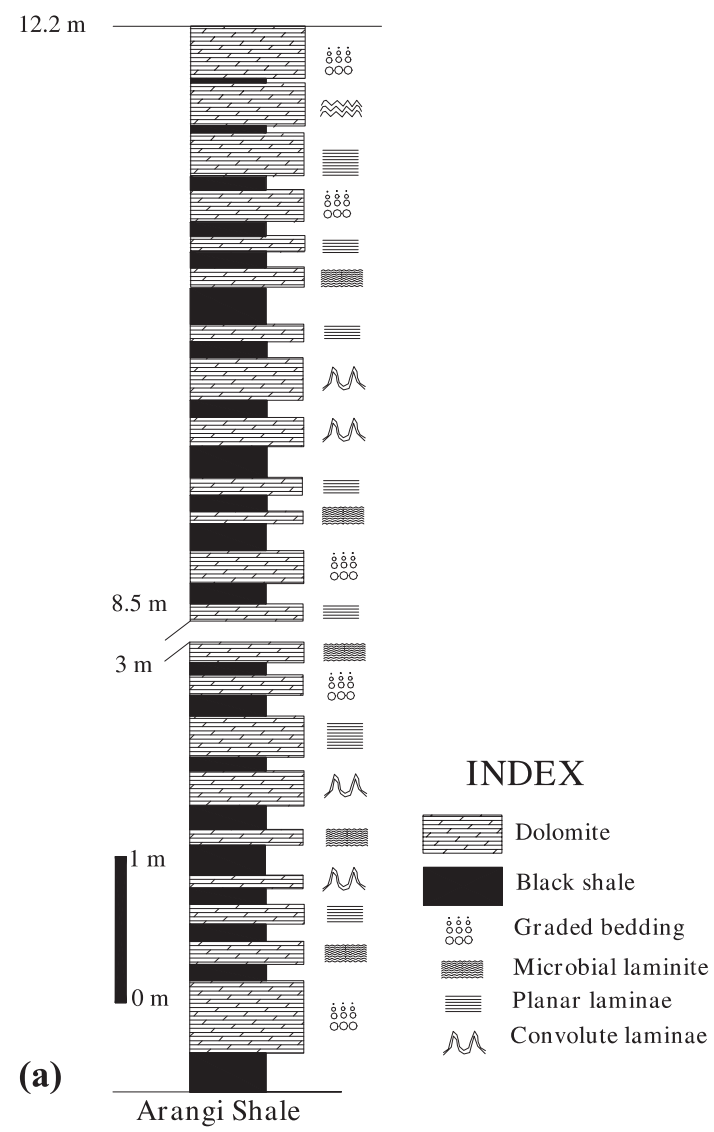

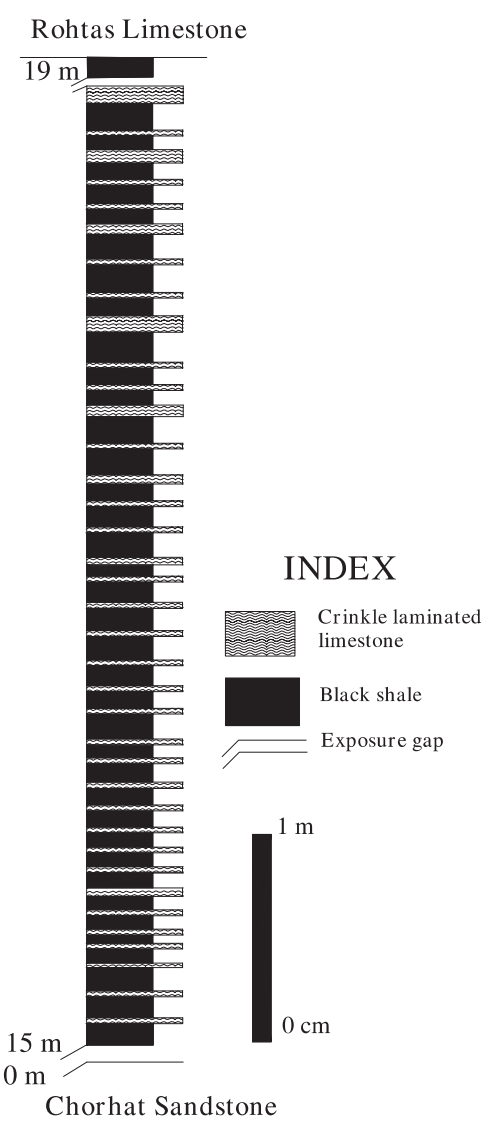

Figure 4. (a) Logs showing black shale and dolomite alternation and associated sedimentary structures in the black shale unit of the Kajrahat Formation and (b) black shale-limestone alternation in the lower part of Rampur Shale.

$11 \mathrm{~cm}$ ) or crinkle laminated dolomite (av. thickness $15 \mathrm{~cm}$ ) (figure 4a). Average thickness of the intervening black shale is $15 \mathrm{~cm}$. The planar laminated dolomite beds have sharper lower contacts and gradational upper contacts. Some of the dolomite beds show graded bedding; convolute laminae are also found in a few cases. The black shale is pyritiferous; pyrite crystals (up to $1.2 \mathrm{~cm}$ length) can be seen within the black shale.

The black shales represent indigenous offshore mud deposits. The planar laminated dolomite represents possible storm deposits. Storm interpretation is supported by the sharp base of the dolomite beds, planar and convolute laminae and occasional graded bedding. The crinkle laminated dolomite resembles microbial laminite. Petrographic study reveals two compositional elements within the black shales:

- continuous to discontinuous clay-dolomite stringers that are intercalated with

- carbonaceous laminae containing a mixture of organic matter, clay, quartz silt and dolosiltite grains.
Carbonaceous laminae exhibit wavy, crinkly texture (figure 5a). Pyrites are present within the carbonaceous laminae. An offshore origin for the black shale unit is proposed on the basis of field and petrographic observations (Banerjee and Schieber 2003).

\subsubsection{Black shales in Rohtas Formation}

The Rohtas Formation is two-tiered, Rampur Shale at the base and the Rohtas Limestone at the top. Rampur Shale abruptly overlies the Chorhat Sandstone. The lower part of the Rampur Shale is overall fining upward in nature and contains siltstone and sandstone interbeds; it passes upward to pyritiferous black shale. The lower part of the Rampur Shale is not exposed in the study area near Ghurma (figure 1). The Rampur Shale in this area is characterized by dark coloured shale (av. thickness $21 \mathrm{~cm}$ ) alternating with thin (usually $<3.5 \mathrm{~cm}$ ) limestone beds (figure $4 \mathrm{~b}$ ) and is locally pyritic in nature. The intervening limestone beds are mostly crinkle laminated and consist of micritic calcites. It gradationally passes upward to Rohtas 

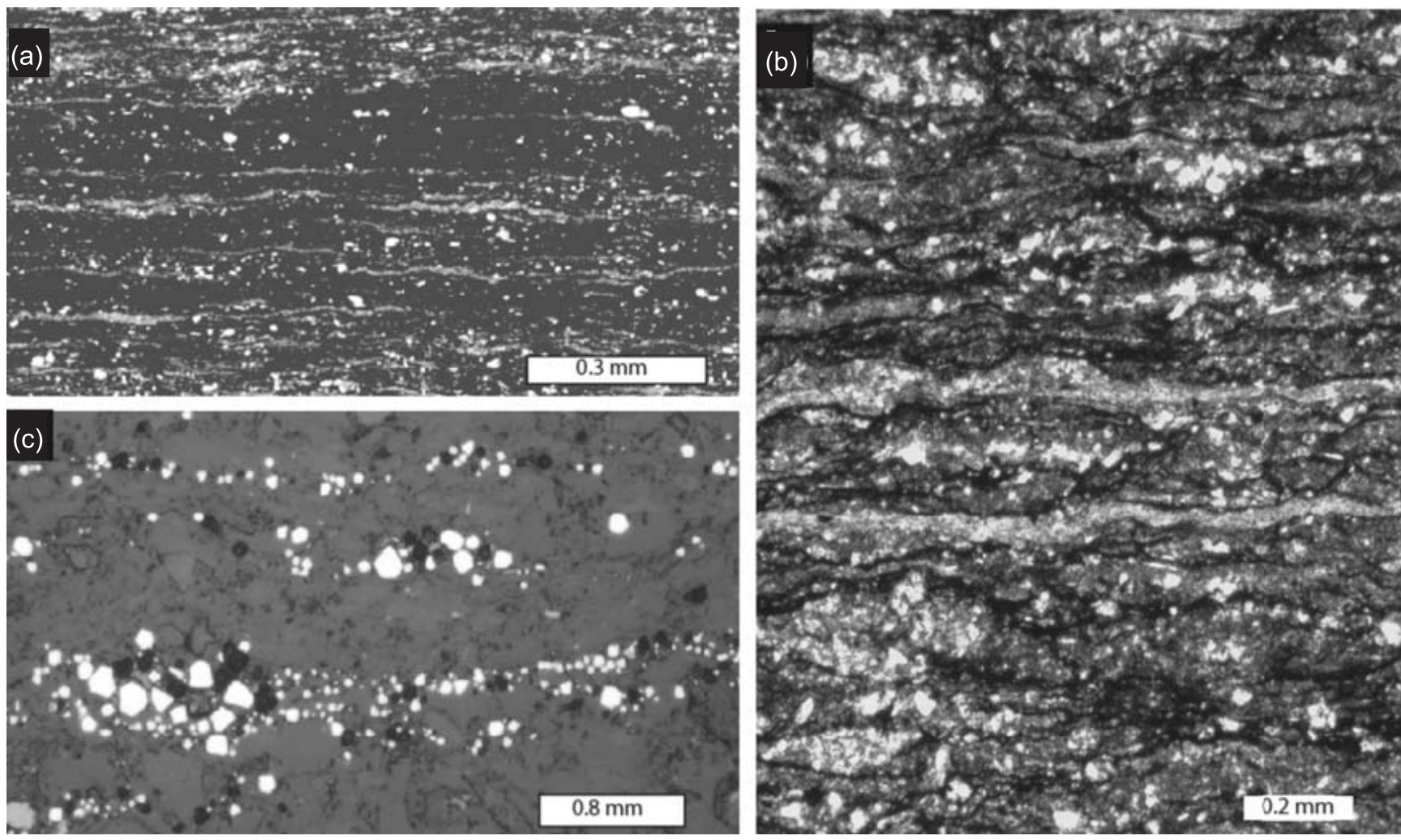

Figure 5. Photomicrographs of black shale under transmitted light showing wavy and crinkly nature in Kajrahat Formation (a) and in Rampur Shale (b). Photomicrograph of black shale under reflected light showing wavy pyritic laminae in top shale (c).

Limestone as the thickness and frequency of limestone beds increase and the shale becomes greyish in colour.

Microfabric study reveals that the black shales consist of clay lenses, dolomicrites, quartz silt and carbonaceous materials. Wavy and crinkly nature is exhibited by the carbonaceous laminae (figure $5 \mathrm{~b}$ ). The meso- and micro-scale features within the black shale unit represents possible outer shelf deposits (see also Sakar et al 2002).

\subsubsection{Black shales within the Kaimur Formation}

The Bijaigarh Shale Member (up to $70 \mathrm{~m}$ thick) at the mid-level of the Kaimur Formation is characterized by organic-rich shale in the Amjhore area (figures 1 and 2). The thickness of the shale gradually decreases towards west and ultimately terminates west of Chopan. It is the only organicrich shale interval of the Upper Vindhyan Group. A pyrite body of average thickness $1.1 \mathrm{~m}$ divides the shale into two divisions, commonly known as bottom shale (av. thickness $32 \mathrm{~m}$ ) and top shale (av. thickness $15 \mathrm{~m}$ ) in Amjhore Pyrite Mines (figure 6). Lower contact of the bottom shale is gradational with the Lower Kaimur Sandstone. The bottom shale is mostly argillaceous, grey to dark grey in colour, and contains intervening siltstone and hummocky cross-stratified sandstone beds. Gutter casts are frequent at the base of the sandstones. Thickness of the sandstones varies from $2 \mathrm{~cm}$ to $12 \mathrm{~cm}$, decreasing from the base of the Bijaigarh Shale to the pyrite band (figure 6). The top shale rests on the pyrite band and gradationally passes over to the Upper Kaimur Sandstone. The top shale is sand free, contains fewer siltstone beds and is less fissile than the bottom shale. Interbedded siltstones vary in thickness from $1 \mathrm{~cm}$ to $4 \mathrm{~cm}$. It is highly carbonaceous and also pyritiferous. The proportion of clay, silt and carbonaceous material may vary within the shale resulting in different types of wavy laminated microfabric. Tiny cubes and octahedral pyrites are abundant within the carbonaceous laminae (figure 5c).

Bottom shale contains abundant siltstone and sandstone beds and is less carbonaceous. Presence of gutter casts possibly suggests storm action and indicates inner shelf setting (see also Chakraborty 1995). High clay content, hummocky cross stratifications, comparatively low pyrite and organic content, carbon content in the bottom shale 


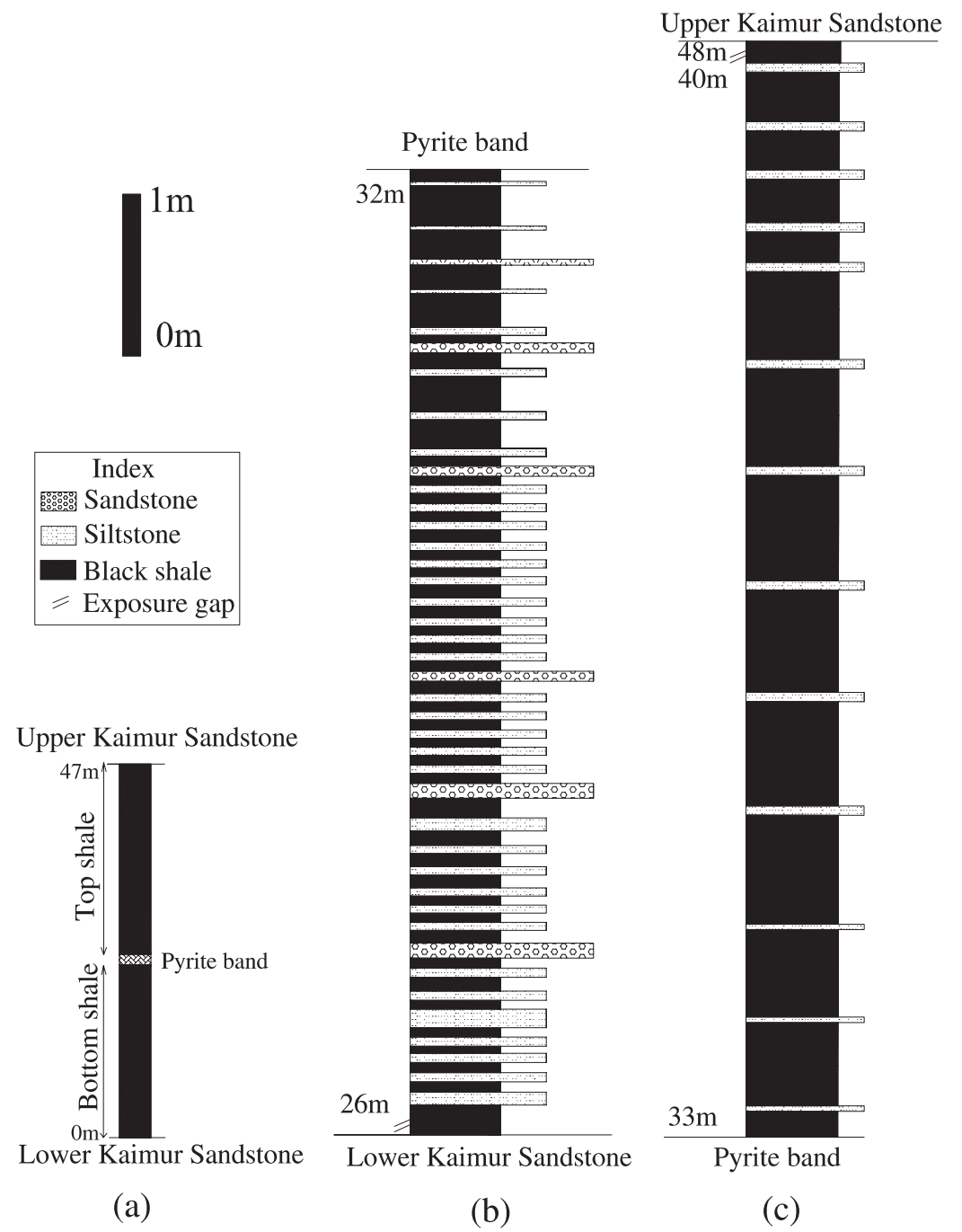

Figure 6. Vertical log showing bottom shale, top shale and pyrite band in Bijaigarh Shale (a). Details of bottom shale and top shale are provided by two vertical logs in the right ( $\mathbf{b}$ and $\mathbf{c}$ respectively).

(table 1) corroborates this interpretation. Lack of sandstones, lower clay content, abundant diagenetic pyrites and higher organic carbon content suggest deeper paleobathymetry of the top shale.

\subsection{Possible sources of organic carbon in the Vindhyan shales}

Wavy, carbonaceous and pyritiferous laminae are very much conspicuous in all the shale units of the Vindhyan Supegroup. The wavy, crinkly carbonaceous laminae of the black shales described above are suggestive of benthic microbial mat growth (cf. Schieber 1986, 1999, 2004). In contrast, Phanerozoic black shales are mostly planar laminated and represent passive accumulation of organic materials. Pyrites following the wavy carbonaceous laminae corroborate the microbial mat origin (Schieber 1986). The black shales represent offshore deposition close to the storm wave base. Violent storms might have interrupted mat growth and deposited the clayey laminae associated with carbonaceous laminae. Microbial mats of possible cyanobacterial origin are the main sources of organic content for these Proterozoic shales (Bauld 1981).

\subsection{Organic matter, sulphur and hydrocarbon content}

\subsubsection{Organic carbon content}

Contents of organic matter expressed by total organic carbon contents (TOC) vary between $0.79 \%$ and $6.44 \%$ (table 1). However, TOC maintains some relationship to individual formations. Relatively low contents are exhibited by the 
Rampur Shale (0.79\%-1.27\%). The bottom shale division of the Bijaigarh Shale demonstrates high TOC values in the range of $1.53 \%-1.89 \%$. Even higher values are observed in the range of $3.83 \%^{-}$ $4.15 \%$ for samples belonging to the top shale division of the Bijaigarh Shale. The samples from Kajrahat Formation also display high values in the range of $2.63-3.14 \%$. The sample from Deoland Formation reveals a very high content of $6.44 \%$.

\subsubsection{Sulphur content}

Total sulphur contents vary between 0.02 and $16.5 \%$ (TS, table 1). In contrast to TOC content, sulphur content does not vary according to individual formations. Nevertheless, three groups with relatively different contents are discriminated. Two samples from the Bijaigarh Shale (B-4 and B-6) of the Kaimur Formation and one sample from the Kajrahat Formation exhibit extremely low values of $0.02-0.05 \%$ sulphur. The three other samples from the Kajrahat Formation and all samples analysed from the Rampur Shale and the Deoland Formation show intermediate sulphur contents of $0.18-0.50 \%$. It is interesting to note that the sulphur content is very high in the two samples from the top shale division of the Bijaigarh Shale $(13.75 \%$ and $16.50 \%)$. This shale is rich in pyrite (Pandalai and Chandra 1984; Paikaray et al $2003)$; it is assumed that most of the sulphur is inorganic.

\subsubsection{Hydrocarbon content}

The fraction of TOC converted by pyrolysis to hydrocarbons and related compounds is referred to as the hydrocarbon index $\left(\mathrm{HI}=\left[\mathrm{S}_{2} / \mathrm{TOC}\right] \times 100\right)$. It is expressed as milligrams of hydrocarbon per gram of total organic carbon (mg HC/g TOC). In general, the evaluated outcrop samples display an extremely low HI-range below $6 \mathrm{mg}$ hydrocarbons per gram TOC. Only the two samples with high sulphur contents have S2 values of 0.12 and $0.14 \mathrm{mg}$ hydrocarbons per gram of rock. All other samples exhibit $\mathrm{S} 2$ values below $0.07 \mathrm{mg}$ hydrocarbons per gram of rock. Thus, all the rock samples investigated bear no hydrocarbon potential. According to the S1 signal, no hydrocarbons occur within the pore spaces of all samples investigated.

\subsubsection{Maturity of organic matter}

The catagenetic stage of organic matter, and its quality were evaluated simultaneously by RockEval pyrolysis. Results are depicted in table 1. During the thermal degradation of kerogen, the

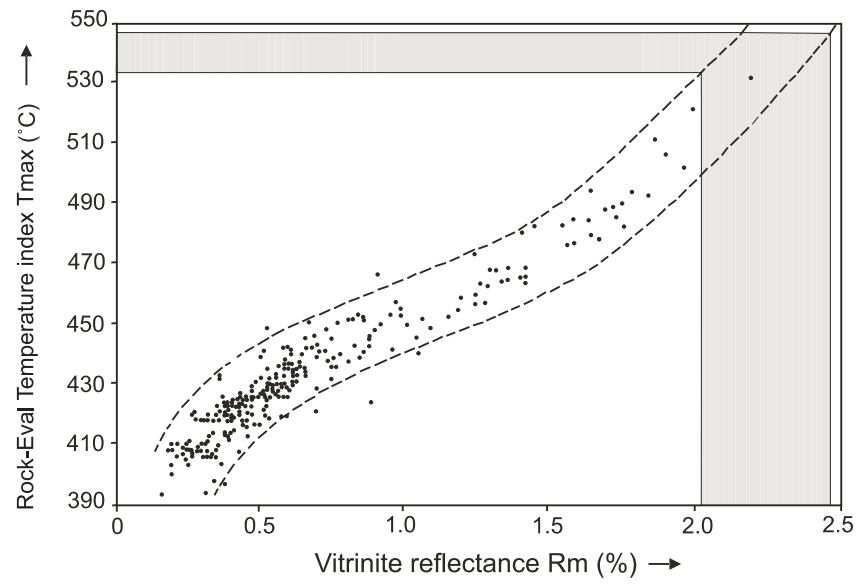

Figure 7. Conversion of Rock-Eval $T_{\max }$-data into vitrinite reflectance according to Teichmüller and Durand (1983).

maximum amount of hydrocarbons and related compounds were released at temperatures between 533 and $551^{\circ} \mathrm{C}(n=13)$. Whereas, eleven samples show a low variation between 533 and $541^{\circ} \mathrm{C}$ (mean $537^{\circ} \mathrm{C}$ ), two relatively high $T_{\max }$ values of 548 and $551^{\circ} \mathrm{C}$ were recorded in the same two samples of the Bijaigarh Shale (B-4 and B-6) which contain high quantities of sulphur. At this stage of investigation, it is not possible to ascertain if the high sulphur contents may have influenced the $T_{\max }$ recordings or if this indicates another type of organic matter, or if these slightly different $T_{\max }$ recordings indicate a real maturity variation. But the absence of any organic-rich shale in preVindhyan formations precludes recycled nature of organic matter. Another important aspect is that despite differences in the present overburden by almost $2 \mathrm{~km}$, all the samples represent the same maturation stage. This may indicate one specific heat flow event which influenced the total sedimentary sequence. Accordingly, the recent geothermal gradient represents only a very minor factor for the Vindhyan shales compared to the long time since they were buried and subjected to various tectonic regimes with probably different heat flows.

According to the established conversion of $T_{\max }$ to vitrinite reflectance, the calculated mean of $537^{\circ} \mathrm{C}$ refers to a vitrinite reflectance range of 2.05-2.40\% $R_{m}$ (figure 7, after Teichmüller and Durand 1983). This indicates a catagenetic stage near the end of the bituminous hard coal stage, close to the beginning of anthracite formation. This stage is confirmed by the low hydrocarbon contents reported above. At this maturation stage, organic matter contains less than $15 \%$ of volatile matter (dry ash free, McCartney and Teichmüller 1972). 


\section{Acknowledgements}

The authors are thankful to David Mossman for his painstaking efforts to improve an earlier version of the manuscript. SB is thankful to the Department of Science and Technology, Govt. of India for financial support. Authors acknowledge their host institutes for providing infrastructural facilities. For elemental analyses, we would like to acknowledge the technical assistance by $\mathrm{F}$ Leistner (Forschungszentrum Jülich, ICG-V).

\section{References}

Ahmad F 1958 Paleogeography of central India in the Vindhyan Period; Rec. Geol. Surv. India 87 513-548.

Auden J B 1933 Vindhyan sedimentation in Son valley; Geol. Surv. India Memoir 62 141-150.

Banerjee S 1997 Facets of the Mesoproterozoic Semri Sedimentation in Son valley, India; Unpubl. Ph.D. thesis, Jadavpur University, Kolkata, 137p.

Banerjee S and Schieber J 2003 Paleoproterozoic condensed zone sediments in the Kajrahat Formation, Vindhyan Supergroup, central India; Geol. Soc. America Abstracts with programs, November 2-5, Seattle 35(6) 173.

Bauld J 1981 Geobiological role of cyanobacterial mats in sedimentary environments: production and preservation of organic matter; BMR J. Austr. Geol. Geophys. 6 307-317.

Bose P K, Sarkar S, Chakraborty S and Banerjee S 2001 Overview of the Meso- to Neoproterozoic evolution of the Vindhyan basin, central India; Sedim. Geol. 141 395-419.

Buick R, Rasmussen B and Krapez B 1998 Archean oil: evidence for extensive hydrocarbon generation and migration 2.5-3.5 Ga; AAPG Bulletin 82 50-69.

Chakraborty C 1995 Gutter casts from the Proterozoic Bijaigarh Shale Formation, India: their implication for storm-induced circulation in shelf settings; Geol. J. 30 69-78.

Chanda S K and Bhattacharyya A 1982 Vindhyan sedimentation and paleogeography: post-Auden developments; In: Geology of Vindhyanchal (eds) Valdiya K S, Bhatia S B and Gaur V K (Delhi: Hindusthan Publishing Corporation) pp. 88-101.

Condie K C, Marais D J D and Abbott D 2001 Precambrian superplumes and supercontinents: a record in black shales, carbon isotopes and paleoclimates? Precamb. Res. $106239-260$

Crick I H 1992 Petrological and maturation characteristics of organic matter from the Middle Proterozoic McArthur Basin, Australia; Australian J. Earth Sci. 39 501-519.

Dickson J A D 1966 Carbonate identification and genesis as revealed by staining; J. Sedim. Petrol. 36 491-505.

Dutkiewicz A, Volk H, Ridley J and George S 2002 Biomarkers, brines, and oil in the Mesoproterozoic, Roper Superbasin, Australia; Geology 31 981-984.

Espitalié J, Laporte J L, Madec M, Marquis F, Leplat P, Paulet J and Boutefeu A 1977 Méthode Rapide de Charactérisation des Roches Mères de leur Potentiel Pétrolier et de leur Degré d'Évolution; Revue de L'Insitut Francais du Pétrole 32 23-42.

Galloway W E 1990 Paleogene depositional episodes, genetic stratigraphic sequences and sediment accumulation rates, NW Gulf of Mexico Basin; GCSSEPM Foundation, Eleveneth Annual Research Conference, Program and Abstracts, pp. 165-176.
Greenwood P F, Aoruri K R, Logan C A and Summons R E 2004 Abundance and geochemical significance of C-2n dialkylanes and highly branched C-3n alkanes in diverse Meso-Neoproterozoic sediments; Org. Geochem. 35 331-346.

Hieshima G B and Pratt L M 1991 Sulfur/carbon ratios and extractable organic matter of the Middle Proterozoic (Nonesuch Formation, North American Midcontinent rift); Precamb. Res. 54 65-79.

Hunt J M 1995 Petroleum Geochemistry and Geology; (New York: W.H. Freeman and Company) 2nd edn, 743p.

Imbus S W, Engel M H, Elmore R D and Zumberge J E 1988 The origin, distribution and hydrocarbon generation potential of organic-rich facies in the Nonesuch Formation, central North American Rift System: A regional study; Org. Geochem. 13 207-219.

Jackson M J and Raiswell R 1991 Sedimentology and carbon-sulphur geochemistry of the Velkerri Formation, a mid-Proterozoic potential oil source in northern Australia; Precamb. Res. 54 81-108.

Katz B J 1983 Limitations of "Rock-Eval" pyrolysis for typing organic matter; Org. Geochem. 4 195-199.

Korsch R J, Mai H, Sun Z and Gorter J D 1991 The Sichuan Basin, southwest China - a Late Proterozoic (Sinian) petroleum province; Precamb. Res. 54 45-63.

McCartney J T and Teichmüller M 1972 Classification of coals according to degree of coalification by reflectance of the vitrinite component; Fuel 51 64-68.

Newell K D, Burruss R C and Palacas J G 1993 Thermal maturation and organic richness of potential petroleum source rocks in Proterozoic Rice Formation, north American midcontinent rift system, northeastern Kansas; Bull. Am. Assoc. Petrol. Geol. 77 1922-1941.

Paikaray S, Banerjee S, Jeevankumar S and Mukherji S 2003 Occurrences of black shales within the Vindhyan Supergroup and its implications; Indian J. Petrol. Geol. 12 65-81.

Pandalai H S and Chandra D 1984 Distribtution of sulphur within the Bijaigarh Shales at Amjhore and a preliminary geochemical study of the pyrite deposit with reference to its origin; Geol. Surv. Spec. Publ. 12 367-371.

Price K L, Huntoon J E and Mcdowell S D 1996 Thermal history of the $1.1 \mathrm{Ga}$ Nonesuch Formation, North American mid-continent rift, White Pine, Michigan; Bull. Am. Assoc. Petrol. Geol. 80 1-15.

Rasmussen B, Bose P K, Sarkar S, Banerjee S, Fletcher I R and Mc Naughton N J 2002 1.6 Ga U-Pb zircon ages for the Chorhat Sandstone, Lower Vindhyan, India: possible implication for early evolution of animals; Geology $\mathbf{3 0}$ 103-106.

Ray J S, Martin M W and Veizer J 2002 U-Pb zircon dating and Sr isotope systematics of the Vindhyan Supergroup, India; Geology 30 131-134.

Ray J S, Veizer J and Davis W J 2003 C, O, Sr and Pb isotope systematics of carbonate sequences of the Vindhyan Supergroup, India: age, diagenesis, correlation and implications for global events; Precamb. Res. 121 103-140.

Sarangi S, Gopalan K and Kumar S $2004 \mathrm{~Pb}-\mathrm{Pb}$ age of earliest megascopic eukaryotic alga bearing Rohtas Formation, Vindhyan Supergroup, India: Implications for Precambrian atmospheric oxygen evolution; Precamb. Res. 132 107-121.

Sarg J F 1988 Carbonate sequence stratigraphy; In: Sealevel changes: an integrated approach; (eds) Wilgus C, Hastings B, Ross C, Posamentier H, Van Wagoner J and Kendall C G.St.C., Soc. Econ. Paleont. Mineral. Spec. Publ. 42 155-181.

Sarkar S, Banerjee S, Chakraborty C and Bose P K 2002 Shelf storm flow dynamics: insight from the 
Mesoproterozoic Rampur Shale, Central India; Sedim. Geol. 147 89-104.

Schieber J 1986 The possible role of benthic microbial mats during the formation of carbonaceous shales in shallow Mid-Proterozoic basins; Sedimentology 33 521-536.

Schieber J 1999 Microbial mats in terrigenous clastics: the challenge of identification in the rock record; Palaios $\mathbf{1 4}$ $3-12$.

Schieber J 2004 Microbial mats in the siliciclastic rock record: a summary of the diagnostic features 7.9; In: The Precambrian Earth: Tempos and Events (eds) Eriksson P G, Altermann W, Nelson D R, Mueller W U and Catuneanu O (Amsterdam: Elsevier) pp. 663-673.

Shukla S N and Chakraborty D 1994 Status of exploration and future programme of hydrocarbon exploration in Vindhyan and Gondwana basins; In: Proceeding of the Second Seminar on Petroliferous basins of India (eds) Biswas S K, Dave A, Garg P, Pandey J, Maithani A and Thomas N J, 3 63-100.

Sur S, Schieber J and Banerjee S 2002 Petrographic observations suggestive of microbial mats and metazoan activity in Middle Proterozoic black shales from India; Geological Society of America Abstracts with programs 34/6 173.

Sur S, Schieber J and Banerjee S 2003 The Bijaigarh and Rampur Shales of the Vindhyan Supergroup, India: transgressive systems tract source rocks of Mid Proterozoic age; AAPG Annual Meeting, Salt Lake City, Utah, May 11-14, A 165.

Sur S, Schieber S and Banerjee S 2004 The geochemistry of the Bijaigarh Shale of the Vindhyan Supergroup, India: a Mid-Proterozoic source rock; AAPG Annual Meeting, Dallas, April 16-18, A 134.

Teichmüller M and Durand B 1983 Fluorescence microscopical rank studies on liptinites and vitrinites in peats and coals, and comparison with results of Rock-Eval pyrolysis; Int. J. Coal Geol. 2 197-230.

Van Wagoner J C, Mitchum R M, Campion K M and Rahmanian V D 1990 Siliciclastic sequence stratigraphy in well logs, cores and outcrops: concepts for highresolution correlation of time and facies. Methods in Exploration Series; Am. Assoc. Petrol. Geol. 7 1-55.

Venkatachala B S, Sharma M and Shukla M 1996 Age and life of Vindhyans: facts and conjectures; In: Recent Advances in Vindhyan Geology; (ed.) Bhattacharyya A, Geol. Soc. India Memoir 36 137-166.

Warren J K, George S C, Hamilton P J and Tingate P 1998 Proterozoic source rocks: Sedimentology and organic characteristics of the Velkerri Formation, Northern Territory, Australia; Bull. Am. Assoc. Petrol. Geol. 82 442-463. 